Asian J. Med. Biol. Res. 2020, 6 (4), 689-696; doi: 10.3329/ajmbr.v6i4.51235

\author{
Asian Journal of \\ Medical and Biological Research \\ ISSN 2411-4472 (Print) 2412-5571 (Online) \\ www.ebupress.com/journal/ajmbr
}

\title{
Article \\ Management of services in total quality management implemented and non- implemented health facilities
}

\author{
Muhsina Begum ${ }^{1 *}$, Ashees Kumar Saha ${ }^{2}$, Sheuly Begum ${ }^{3}$, Nasima Akhter ${ }^{4}$, Pritikona Borua ${ }^{5}$ and Baizid \\ Khoorshid Riaz ${ }^{6}$
}

${ }^{1}$ Mugda Medical College Hospital, Mugda, Dhaka, Bangladesh

${ }^{2}$ Nursing Officer, Upazila Health Complex, Bagha, Rajshahi, Bangladesh

${ }^{3}$ Shaheed Tajuddin Ahmed Nursing College, Gazipur, Bangladesh

${ }^{4}$ Dinajpur Nursing College, Dinajpur, Bangladesh

${ }^{5}$ Fouzderhat Nursing College, Chattagram, Bangladesh

${ }^{6}$ NIPSOM, Mohakhali, Dhaka, Bangladesh

*Corresponding author: Muhsina Begum, Mugda Medical College Hospital, Mugda, Dhaka, Bangladesh.

Phone: +8801715411218; E-mail: muhsina.mona82@gmail.com

Received: 10 November 2020/Accepted: 19 December 2020/ Published: 31 December 2020

\begin{abstract}
S-CQI-TQM is a management technique that is aimed at bringing satisfaction of staff as well as the patients through improvement of working environment. A cross-sectional comparative study was carried out among 226 respondents who were selected purposively from the selected study place from $1^{\text {st }}$ January to $31^{\text {st }}$ December 2017. Among 226 respondents, 113 were taken from Dhaka Medical College and another 113 were taken from Mugdha Medical College. Among 113 respondents, 56 respondents were health care providers and 57 respondents were health care receivers. The purpose of this study to compare the management of services in Total Quality Management implemented (Dhaka Medical College and Hospital) and non-implemented (Mugdha Medical College and Hospital) health facilities. A Semi-structured interviewer administered questionnaire and an observational check list were developed to collect the data. Separate questionnaire was used for health care providers and health care receivers. The statistical analysis was conducted using SPSS (statistical package for social science) version 20 statistical software. Significant statistical differences were found between TQM implemented and TQM non-implemented hospital regarding workload $(\mathrm{p}=0.043)$, hospital authority always seriously consider staff's suggestions for the improvement of quality of service $(p<0.001)$, employees always respect to each other in the hospital $(\mathrm{p}<0.001)$ and $35(62.5 \%)$ service providers expressed satisfactory opinion regarding management of the hospital.
\end{abstract}

Keyword: total quality management; quality; management of services; patient management; service provider; service receiver

\section{Introduction}

Total Quality Management (TQM) is one of the most prominent developments in management for the past two decades. TQM started in Japan in the early 1980s and spread to the Western countries and Australia. In the 1990s, TQM topics became very important, and many companies were looking to apply TQM and use it to develop and improve their businesses (Pourrajab et al., 2012). Total Quality Management is defined as "a management philosophy concerned with people and work processes that focuses on customer satisfaction and improves organizational performance". These days, health organizations face many challenges that can be classified into four major areas: increases in the cost of health services, rapidly growing technology dependence, pressure on health organizations to decrease costs and improve quality to cope with the international organizations that establish standards and give licenses and finally satisfying patients' needs, a major demand requiring hospitals to maintain high quality services. Such challenges force health planners to adopt a system that can manage health care in a measurable way to offer a high quality service, which is the aim of the quality 
management programs in hospitals. The system that can cope with all of these challenges and resolve all health organization's problems is TQM. Total Quality Management is also known as continuous quality improvement (CQI), quality improvement (QI), quality management (QM) and total quality control (TQC). Experts indicate that the key principles of TQM include the following: customer focus, obsession with quality, scientific approach, long-term commitment, teamwork, and continual improvement systems, education, and training, freedom through control, unity of purpose and employee involvement and empowerment (Al-Shdaifat, 2015).

Quality management has become an important issue in healthcare organizations (hospitals) during the last couple of decades. The increased attention to quality is due to governmental regulations, influence of customers, and hospital management initiatives (Balasubramanian, 2016).

5S-CQI-TQM is a management technique that was used intestinally in Japan in industrial sector. This technique was then applied in hospital setting to improve quality of services. In South-East-Asia, Sri Lanka has successfully applied this methodology at the public hospitals for improvement of quality of services.

This technique is currently being practiced in several African and Asian countries including Bangladesh. 5SCQI-TQM is a participatory management approach where everybody participates. The 5S (Sort, Set, Shine, Standardize and Sustain) is aimed at bringing satisfaction of staff as well as the patients through improvement of working environment. The next step of the process is CQI or continuous quality improvement, directed to improve the management system/process. TQM (total quality management) is achieved through achievement of $5 \mathrm{~S}$ and incremental but continuous improvement of service delivery process (Manual for Implementation of $5 \mathrm{~S}$ in Hospital Setting, 2015).

PDCA (Plan-Do-Check-Act) is an iterative, four-stage approach for continually improving processes, products or services, and for resolving problems. It involves systematically testing possible solutions, assessing the results, and implementing the ones that have shown to work. It is based on the scientific method of problemsolving and was popularized by Dr W. Edwards Deming, who is considered by many to be the father of modern quality control. The PDCA Cycle provides a simple and effective approach for solving problems and managing change (Skhmot, 2017).

Goal of the "three-step-approach, "5S-CQI-TQM", is not just to introduce 5S or CQI at the hospitals, but to bring changes in organizational (hospital) culture and management style. Healthcare delivery should be outcome-oriented and patient-centered. Safety and Quality are the essential features of the outcome. Responsiveness and equity are the core components of patient-centeredness. To achieve those goals participatory approach is essential. Regardless of the categories and ranks of the hospital staff, full participation of the employees should be encouraged through accumulation of small successes in the routine work. Teambuilding should be vigorously done to strengthen continued team work in every work unit of the hospital (Manual for Implementation of 5S in Hospital Setting, 2015).

One of the main challenges Bangladesh faces in moving toward Universal Health Coverage is the quality of health care services. In order to keep the population healthy as required to sustain a rapid economic growth, more effective and safer health-care services are essential. As the economy keeps growing, the demand for more complex health care increases. 5S-CQI-TQM will help hospitals proceed to provide better standard of care and services (Chief Representative's Speech, 2015)

The 5S-CQI-TQM activity under the partnership between DGHS (Directorate General of Health Services) and JICA started in February 2011 at Narsingdi District Hospital. Introduced in 2011, the process is being implemented in more than 120 hospitals in Bangladesh (Islam, 2011).

The present study aimed to compare the management of services in Total Quality Management implemented and non-implemented health facilities.

\section{Materials and Methods}

\subsection{Ethical consideration}

This study was conducted with the intention of protecting the human rights of all subjects. All the information collected for the study was utilized only for the purpose of thesis and was not disclosed to anyone outside the research team. At the beginning, approval was obtained from the ethical committee of NIPSOM, under the Bangabandhu Sheikh Mujib Medical University, Dhaka, Bangladesh. Before collection of data, written permission was taken from the director of the corresponding hospital and also informed written consent was obtained from participants after informing about the purpose of the study. A complete assurance was given that all information keeps confidentially. Their participation and contribution was acknowledge with due respects. The right was being given to the participants not to participate and to discontinue participation at any time in study with consideration/without penalty. Informed consent will be documented properly. Each respondent was 
interviewed separately and their privacy and confidentiality was maintained strictly. Outcome of the study would be public health importance.

\subsection{Study design}

The study was a cross sectional comparative study. Data were collected from respondents once only.

\subsection{Study population}

Health care providers and health care receivers of Dhaka Medical College and Hospital and Mugdha Medical College and Hospital.

\subsection{Study period and others}

The study period was 1st January to 31th December, 2017.

\subsubsection{Place of study}

The study was carried in Dhaka Medical College and Hospital and Mugdha Medical College and Hospital.

\subsubsection{Sampling technique}

The sample was collected by purposive sampling technique who fulfilled the selection criteria. Sample size were 226.

\subsubsection{Inclusion criteria}

For healthcare provider, the inclusion criteria were, permanent employee of the institution irrespective of age, gender and religion and having work experience in the study place for more than six months. For healthcare receiver, the criteria was willing to participate in the study.

\subsubsection{Exclusion criteria}

For healthcare provider, exclusion criteria were, respondents who were on leave or training and unwilling to participate in this study. For healthcare receiver exclusion criteria were mentally retarded patients and severely ill patients.

\subsubsection{Tool of the study}

Semi-structured interviewer administered questionnaire was developed to collect the data. Separate questionnaire was used for health care providers and health care receivers. First part of the questionnaire included information regarding health care providers. Second part of the questionnaire contained questions regarding health care receivers. Checklist was used to collect information regarding administrative facility, physical facility and utility services. The questionnaire was first developed in English version and then translated into Bengali. Data from the respondents were collected through face-to-face interview.

\section{Results and Discussion}

This cross-sectional comparative study was carried out among 226 respondents to compare the management of services in Total Quality Management implemented (Dhaka Medical College and Hospital) and nonimplemented (Mugdha Medical College and Hospital) health facilities.

Table 1 showed the mean age of TQM implemented hospital service providers was $36.26( \pm 10.07)$ years and the mean age of non-implemented hospital service providers was $34.30( \pm 6.6)$ years. On the other hand the mean age of TQM implemented hospital service receivers was $38.28( \pm 15.44)$ years and the mean age of TQM-non implemented hospital service receivers was $37.47( \pm 16.13)$ years. Majority of the service providers of TQM implemented hospital and non-implemented hospital were female $47(83.9 \%)$ and $45(80.6)$ even same as service receivers like 39 (68.4) and 40 (70.2). Most of the respondents in TQM implemented and nonimplemented hospital were nurse 31 (55.4) and 26 (46.4). Majority of service receivers of TQM implemented and non-implemented hospital was house wives. Here the mean monthly family income of TQM implemented hospital service receivers was $20,230( \pm 13,120.00)$ taka and TQM-non implemented hospital service receivers was $16,280( \pm 26,480.00)$ taka. 
Table 1. Socio-demographic characteristics of service provider and service receivers.

\begin{tabular}{|c|c|c|}
\hline \multicolumn{3}{|c|}{ Comparison of service providers by age } \\
\hline Age (in years) & TQM implemented hospital, $\mathrm{n}(\%)$ & TQM non-implemented hospital, $\mathrm{n}(\%)$ \\
\hline $21-30$ & $20(35.8)$ & $18(32.1)$ \\
\hline $31-40$ & 20(35.8) & $30(53.6)$ \\
\hline $40-60$ & $16(28.4)$ & $8(14.3)$ \\
\hline Total & $56(100)$ & $56(100)$ \\
\hline Mean \pm SD & $36.26 \pm 10.07$ & $34.30 \pm 6.6$ \\
\hline \multicolumn{3}{|c|}{ Comparison of service receivers by age } \\
\hline 18 to 27 & $23(40.4)$ & $22(38.6)$ \\
\hline $28-37$ & $7(12.3)$ & $10(17.5)$ \\
\hline $38-47$ & $8(14.0)$ & $8(14.0)$ \\
\hline Above 47 & 19(33.3) & $17(29.9)$ \\
\hline Total & $57(100)$ & $57(100)$ \\
\hline Mean \pm SD & $38.28 \pm 15.44$ & $37.47 \pm 16.13$ \\
\hline \multicolumn{3}{|c|}{ Comparison of service providers by sex } \\
\hline Male & $9(16.1)$ & $11(19.6)$ \\
\hline Female & 47 (83.9) & $45(80.6)$ \\
\hline \multicolumn{3}{|c|}{ Comparison of service receivers by sex } \\
\hline Male & $18(31.6)$ & $17(29.8)$ \\
\hline Female & $39(68.4)$ & 40 (70.2). \\
\hline \multicolumn{3}{|c|}{ Comparison of service providers by designation } \\
\hline Doctor & $15(26.8)$ & $18(32.1)$ \\
\hline Nurse & $31(55.4)$ & $26(46.4)$ \\
\hline Supporting staff & $10(17.9)$ & $12(21.4)$ \\
\hline \multicolumn{3}{|c|}{ Comparison of service receivers by occupational status } \\
\hline House wife & $30(52.6)$ & 37 (64.9) \\
\hline Service holder & $9(15.8)$ & $6(10.5)$ \\
\hline Student & $0(0.0)$ & $6(10.5)$ \\
\hline Business & $3(5.3)$ & $3(5.3)$ \\
\hline Jobless & $9(15.8)$ & $1(1.8)$ \\
\hline $\begin{array}{l}\text { Others (shop keeper, driver, day } \\
\text { labor and agricultural worker) }\end{array}$ & $6(10.5)$ & $4(7.2)$ \\
\hline \multicolumn{3}{|c|}{ Comparison of service receivers by monthly family income (in taka) } \\
\hline $5000-10,000$ & $14(24.6)$ & $37(64.9)$ \\
\hline $11000-15000$ & $15(26.3)$ & $9(15.8)$ \\
\hline $16000-20000$ & $8(14.0)$ & $4(7.0)$ \\
\hline Above 20000 & $20(35.1)$ & $7(12.3)$ \\
\hline Total & $57(100)$ & $57(100)$ \\
\hline Mean $\pm \mathrm{SD}$ & $20,230 \pm 13,120.00$ & $16,280 \pm 26,480.00$ \\
\hline
\end{tabular}

Table 2 showed that majority of the service providers (78.8\%) stated that necessary equipment was always supplied in TQM implemented hospital whereas majority of the service providers (64.3\%) stated that necessary equipment was sometimes supplied in TQM non-implemented hospital. In TQM implemented hospital, 82.1\% $(\mathrm{n}=46)$ service providers stated that necessary medicine was always supplied whereas in majority of the service providers $(67.9 \%)$ stated that necessary medicine was sometimes supplied in TQM non-implemented hospital. Both in TQM implemented and TQM non-implemented hospital, majority of the service providers stated that necessary stationeries were always supplied. Majority of the service providers $(51.8 \%)$ in TQM implemented hospital stated that they faced problems due to lack of skilled personnel while doing job. In TQM nonimplemented hospital most of the service providers $(91.1 \%)$ stated that they faced problems due to lack of skilled personnel whereas majority of them (53.5\%) mentioned about inadequate investigation facility. In TQM implemented and TQM non-implemented hospital, majority of the service providers stated that proper supervision and monitoring could overcome the problem. In TQM non-implemented hospital, 46 (82.1\%) service providers stated that increase no. of skilled personnel could overcome the problem. 
Table 2. Comparison of service providers by opinion regarding hospital supply, problems faced by them while doing job and to overcome the problems.

\begin{tabular}{|c|c|c|}
\hline Hospital supply & TQM implemented hospital, n (\%) & $\begin{array}{l}\text { TQM non-implemented } \\
\text { hospital, n (\%) }\end{array}$ \\
\hline \multicolumn{3}{|l|}{ Necessary equipment } \\
\hline Always & 43(78.8) & $20(35.7)$ \\
\hline Sometimes & 14(21.4) & $36(64.3)$ \\
\hline \multicolumn{3}{|l|}{ Necessary medicines } \\
\hline Always & $46(82.1)$ & $18(32.1)$ \\
\hline Sometimes & $10(17.9)$ & $38(67.9)$ \\
\hline \multicolumn{3}{|l|}{ Necessary stationeries } \\
\hline Always & 46(78.9) & $43(76.8)$ \\
\hline Sometimes & $10(17.9)$ & $13(23.2)$ \\
\hline \multicolumn{3}{|c|}{ Comparison of service providers by opinion regarding the problems faced by them while doing job } \\
\hline Lack of skilled personnel & $29(51.8)$ & $51(91.1)$ \\
\hline Inadequate equipment & $7(12.5)$ & $9(16.1)$ \\
\hline Inadequate medicine & $7(12.5)$ & $8(14.3)$ \\
\hline Inadequate investigation facility & $7(12.5)$ & $30(53.5)$ \\
\hline Sudden accident & $5(8.8)$ & $2(3.6)$ \\
\hline \multicolumn{3}{|c|}{ Comparison of service providers by opinion to overcome the problems } \\
\hline Proper supervision and monitoring & $31(55.3)$ & $36(64.3)$ \\
\hline Twenty four hour help desk facility & $8(14.3)$ & $8(14.3)$ \\
\hline Pharmacy for indoor patients & $4(7.1)$ & $9(16.1)$ \\
\hline Increase no. of skilled personnel & $7(12.5)$ & $46(82.1)$ \\
\hline
\end{tabular}

Table 3 showed that in TQM implemented hospital majority of the service providers i.e. $30(53.6 \%)$ faced high workload and rests 26 (46.4\%) faced average workload. In TQM non-implemented hospital, 41 (73.2\%) service providers faced high workload and $14(25.0 \%)$ faced average workload. Significant statistical differences was found regarding workload between TQM implemented and TQM non-implemented hospital ( $\mathrm{p}=0.043$, obtained by Chi-square test).

Table 3. Association of service providers by workload, authorities' consideration about staff's suggestions and employees respect to each other.

\begin{tabular}{|c|c|c|c|}
\hline Workload & $\begin{array}{l}\text { TQM implemented } \\
\text { hospital, } \mathbf{n}(\%)\end{array}$ & $\begin{array}{l}\text { TQM non-implemented } \\
\text { hospital, } \mathbf{n}(\%)\end{array}$ & Statistics \\
\hline Low & $0(0.0)$ & $1(1.8)$ & $\chi^{2}=6.304^{\mathrm{a}}$ \\
\hline Average & $26(46.4)$ & $14(25.0)$ & $\mathrm{df}=2$ \\
\hline High & $30(53.6)$ & $41(73.2)$ & $\mathrm{p}=0.043$ \\
\hline Total & $56(100)$ & $56(100)$ & \\
\hline \multicolumn{4}{|c|}{ Association of service providers by opinion on hospital authorities' consideration about staff's suggestions } \\
\hline Always & $33(58.9)$ & $11(19.6)$ & $\chi^{2}=23.615^{\mathrm{a}}$ \\
\hline Sometimes & $20(35.7)$ & $45(80.4)$ & $\mathrm{df}=2$ \\
\hline Never & $3(5.4)$ & $0(0.0)$ & $\mathrm{p}<0.001$ \\
\hline Total & $56(100)$ & $56(100)$ & \\
\hline \multicolumn{4}{|c|}{ Association of service providers by opinion on employees respect to each other } \\
\hline Always & 48(85.7) & $6(10.7)$ & $\chi^{2}=63.080^{\mathrm{a}}$ \\
\hline Sometimes & $8(14.3)$ & $50(89.3)$ & $\mathrm{df}=1$ \\
\hline Total & $56(100)$ & $56(100)$ & $\mathrm{p}<0.001$ \\
\hline \multicolumn{4}{|c|}{ Association of service providers by opinion on management of the hospital } \\
\hline Satisfactory & $35(62.5)$ & $25(44.6)$ & $\chi^{2}=9.750^{\mathrm{a}}$ \\
\hline Average & $17(30.4)$ & $31(55.4)$ & $\mathrm{df}=2$ \\
\hline Unsatisfactory & $4(7.1)$ & $0(0)$ & $\mathrm{p}=0.008$ \\
\hline
\end{tabular}

Matter of authorities' consideration about staff's suggestions in TQM implemented hospital, majority of the respondents i.e. $33(58.9 \%)$ gave opinion that hospital authority always seriously consider staff's suggestions for the improvement of quality of service. On the other hand, in TQM non-implemented hospital, majority of the respondents i.e. $45(80.4 \%)$ gave opinion that hospital authority sometimes seriously consider staff's 
suggestions for the improvement of quality of service. Highly significant $(p<0.001)$ statistical differences was found regarding hospital authority always seriously consider staff's suggestions for the improvement of quality of service between TQM implemented and non-implemented hospital (obtained by Chi-square test).

Regarding employees respect to each other in TQM implemented hospital, most of the respondents i.e. 48 (85.7\%) gave opinion that employees always respect to each other in the hospital. On the other hand, in TQM non-implemented hospital, most of the respondents i.e. 50 (89.3\%) gave opinion that employees sometimes respect to each other in the hospital. Highly significant $(\mathrm{p}<0.001)$ statistical differences was found regarding employees always respect to each other in the hospital between TQM implemented and non-implemented hospital (obtained by Fisher's Exact test).

Majority of the service providers i.e. 35 (62.5\%) expressed satisfactory opinion regarding management of the hospital. On the other hand, in TQM non-implemented hospital, majority of the service providers i.e. 31 (55.4\%) expressed average opinion regarding management of the hospital. Highly significant $(p=0.008)$ statistical differences was found regarding opinion on management of the hospital between TQM implemented and nonimplemented hospital (obtained by Chi-square test).

Table 4 showed that 45 (78.9\%) service receivers of both TQM implemented and TQM non-implemented hospital were received by nurses and rests $(21.1 \%)$ were received by doctors. Treatment was initiated on time in case of most of the i.e. $54(94.7 \%)$ service receivers of TQM implemented hospital. All of the service receivers i.e. $57(100.0 \%)$ of TQM non-implemented hospital got treatment timely. In both TQM implemented and nonimplemented hospitals, investigation facility, blood bank facility, medicine facility, radiology and imaging facility, physiotherapy facility, social welfare were present and all the necessary equipment, medicines and investigation facilities were sometimes available. Structured health education session for the patients and attendants were present in TQM implemented hospital. Medical records were kept by technicians and nurses in TQM implemented and non-implemented hospital accordingly. Conduction of client satisfaction survey at regular interval was present only in TQM implemented hospital.

Table 4. Comparison of service receivers by person who received them, initiation of treatment and Comparison of support services.

\begin{tabular}{|c|c|c|}
\hline Person who received the service receiver & $\begin{array}{l}\text { TQM implemented } \\
\text { hospital, } \mathbf{n}(\%)\end{array}$ & $\begin{array}{l}\text { TQM non-implemented } \\
\text { hospital, } \mathbf{n}(\%)\end{array}$ \\
\hline Doctor & $12(21.1)$ & $12(21.1)$ \\
\hline Nurse & $45(78.9)$ & $45(78.9)$ \\
\hline Total & $57(100)$ & $57(100)$ \\
\hline \multicolumn{3}{|c|}{ Comparison of service receivers by opinion on initiation of treatment } \\
\hline On time & $54(94.7)$ & $57(100.0)$ \\
\hline Have to wait & $3(5.3)$ & $0(0.0)$ \\
\hline Total & $57(100)$ & $57(100)$ \\
\hline \multicolumn{3}{|l|}{ Comparison of support services } \\
\hline Investigation facility & Present & Present \\
\hline Blood bank facility & Present & Present \\
\hline Medicine facility & Present & Present \\
\hline Radiology and imaging facility & Present & Present \\
\hline Physiotherapy facility & Present & Present \\
\hline Social welfare & Present & Present \\
\hline $\begin{array}{l}\text { All the necessary equipment are supplied to patients from the } \\
\text { hospital }\end{array}$ & Sometimes & Sometimes \\
\hline $\begin{array}{l}\text { All the necessary medicines are supplied to patients from the } \\
\text { hospital }\end{array}$ & Sometimes & Sometimes \\
\hline Necessary investigation facilities are available in the hospital & Sometimes & Sometimes \\
\hline $\begin{array}{l}\text { Structured health education session for the patients and } \\
\text { attendants }\end{array}$ & Present & Absent \\
\hline Action taken on the basis of public complaints & Absent & Absent \\
\hline Medical record facilities & Available & Available \\
\hline Who keeps the records & Technician & Nurse \\
\hline How is the record kept & Manually & Manually \\
\hline Store room for medicines and other necessary equipment & Available & Available \\
\hline Conduction of client satisfaction survey at regular interval & Present & Absent \\
\hline
\end{tabular}




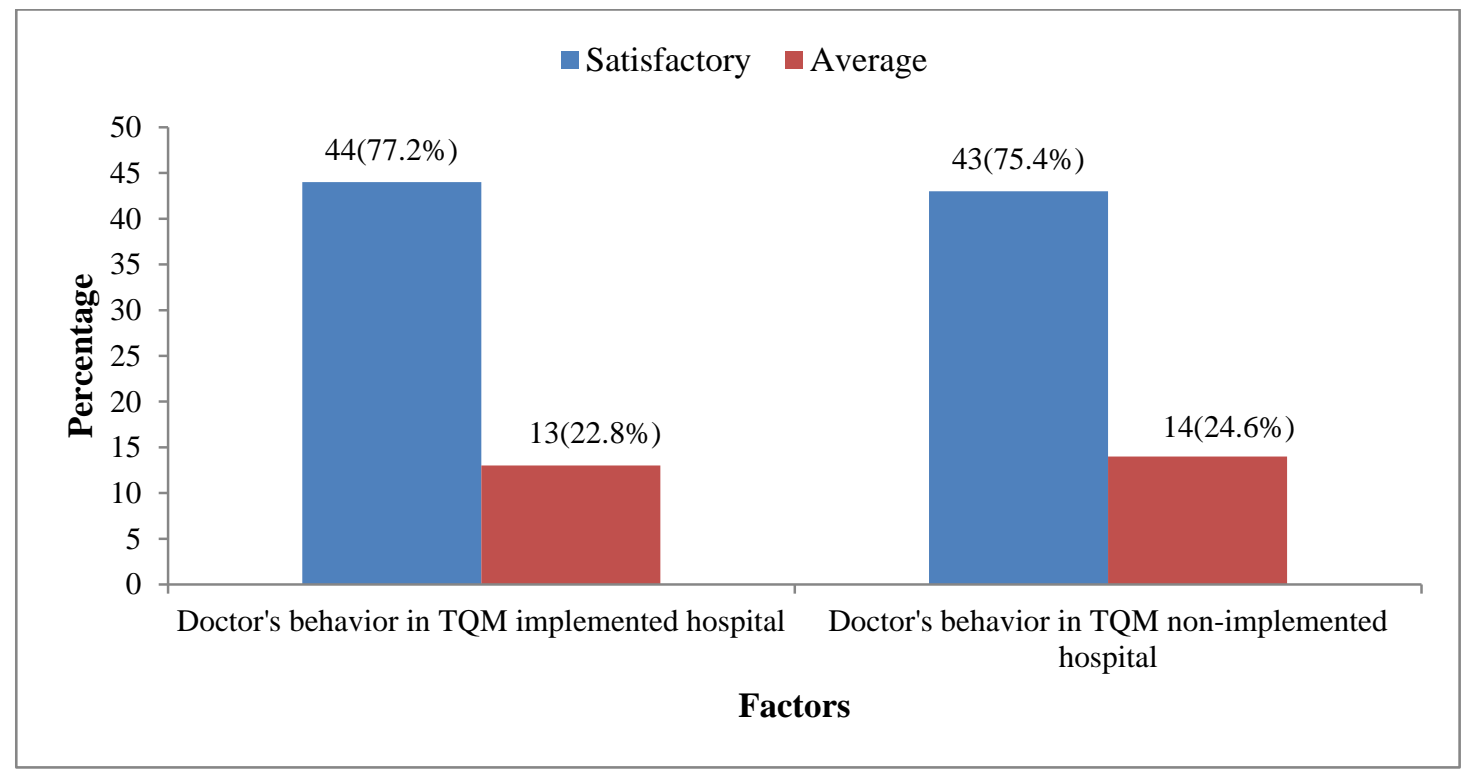

Figure 1. Comparison of service receivers by opinion on doctor's behavior.

Figure 1 showed that in TQM implemented hospital, 44 (77.2\%) service receivers expressed satisfactory opinion on doctor's behavior. On the other hand, in TQM non-implemented hospital 43 (75.4\%) service receivers expressed satisfactory opinion on doctor's behavior.

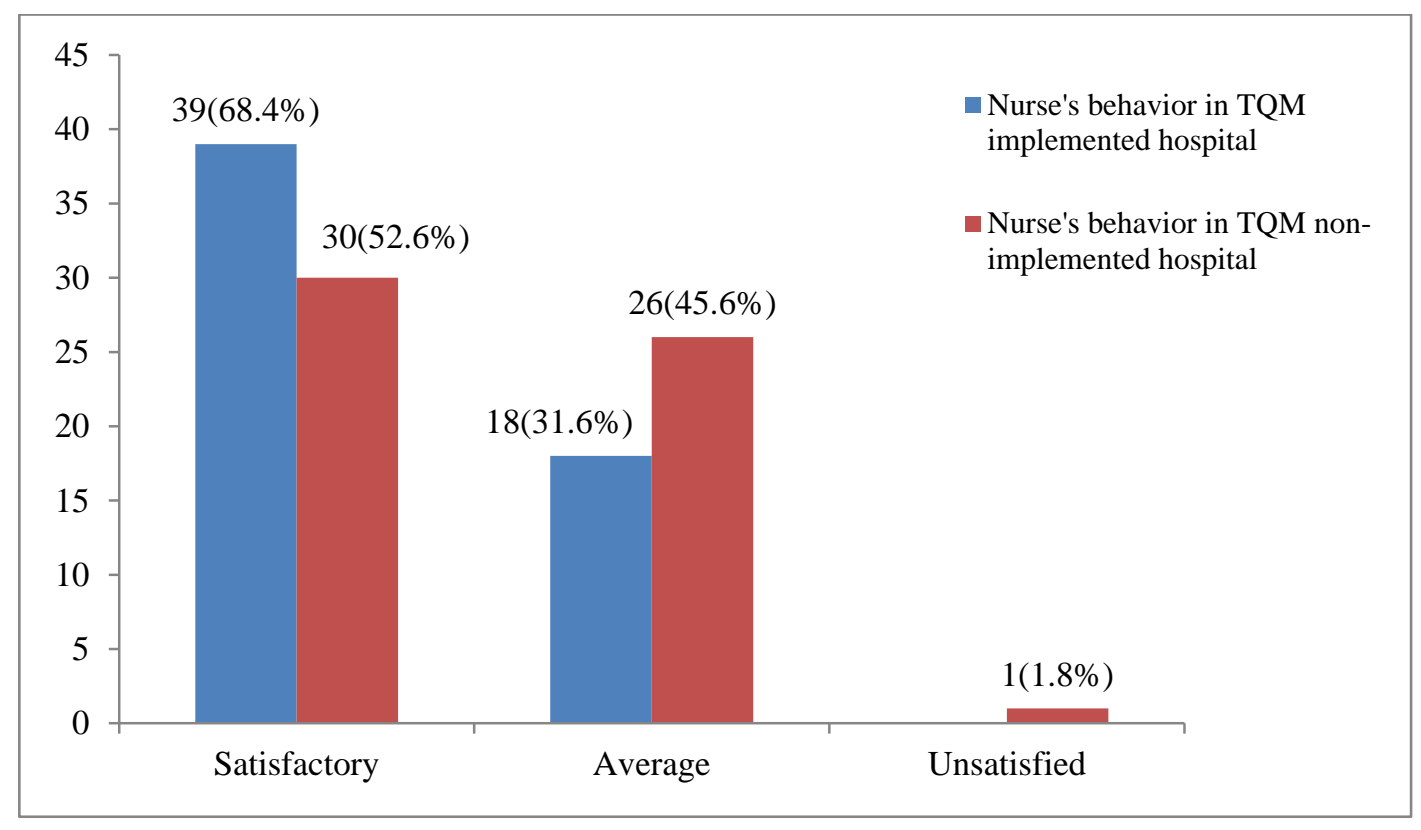

Figure 2. Comparison of service receivers by opinion on nurse's behavior.

Figure 2 showed that in TQM implemented hospital, majority of the service receivers i.e. $39(68.4 \%)$ expressed satisfactory opinion on nurse's behavior. On the other hand, in TQM non-implemented hospital 26 (45.6\%) service receivers expressed average opinion on nurse's behavior.

\section{Conclusions and Recommendations}

TQM is the system of activities directed at achieving delighted customers, empowered employees, higher revenues, and lower costs. Overall management system was found better in TQM implemented hospital than TQM non-implemented hospital. Providing training on TQM to service providers, increasing number of skilled health service provider and be strengthening proper supervision and monitoring system could make the management better in both hospitals. the recommendations can be putted forward, TQM non-implemented hospital should implement TQM for better management, both hospital employees should be trained on TQM, 
number of skilled health service provider should be increased, proper supervision and monitoring system should be strengthened, investigation facilities should be made more for patients, and dietary facility should be improved in TQM implemented hospital.

\section{Conflict of interest}

None to declare.

\section{References}

Al-Shdaifat EA, 2015. Implementation of total quality management in hospitals. Journal of Taibah University Medical Sciences, 10: 461-466.

Balasubramanian M, 2016. Total Quality Management [TQM] in the healthcare industry - challenges, barriers and implementation developing a framework for tqm implementation in a healthcare setup. Sci. J. Pub. Heal., 4: 271-278.

Chief Representative's Speech, 2015. 5S-CQI-TQM Best Performing Hospital Award Giving Ceremony. Available at: https://www.jica.go.jp/bangladesh/english/office/topics/speech150602.html (Retrieved on September 2017)

Islam T, 2011. 5S-CQI-TQM For Hospital Management Improvement' available at: http://dns.gov.bd/cmsfiles/files/5_\%205S_Nurses_Taj.pdf (Retrieved on 19 $9^{\text {th }}$ June 2017).

Skhmot N, 2017. Using the PDCA Cycle to Support Continuous Improvement (Kaizen). Available at: https://theleanway.net/the-continuous-improvement-cycle-pdca. (Retrieved on October 2017)

Manual for Implementation of 5S in Hospital Setting, 2015. Directorate General of Health Services Ministry of Health and Family Welfare Directorate General of Health Services. Available at: https://www.jica.go.jp/activities/issues/health/5S-KAIZEN-TQM-02/ku57pq00001pi3y4-att/ban_01.pdf

Pourrajab M, Basri R, Daud SM, Asimiran S and S Mousavy, 2012. The relationship between level of total quality management (TQM) and the level of culture of teaching and learning (COTL) in school. Int. J. Res. Man. Sci. Tech., 2: 319. 